\title{
Irrigation Regimes Affect Yield and Water Use by Bell Pepper
}

\author{
Doyle A. Smittle ${ }^{1}$, W. Lamar Dickens ${ }^{1}$, and James R. Stansell ${ }^{2}$ \\ University of Georgia, Coastal Plain Experiment Station, Tifton, GA 31793
}

Additional index words. Capsicum annuum, soil water tension, evapotranspiration, evaporation, crop factor, irrigation scheduling, water-use modeling

\begin{abstract}
Keystone Resistant Giant' bell pepper (Capsicum annuum L.) was grown in drainage lysimeters under controlled soil water regimes during 1982, 1984, and 1985. Three irrigation regimes were imposed on bell pepper grown on two soil types during spring and fall growing seasons. Irrigation regimes consisted of applying water when the soil water tension at $10 \mathrm{~cm}$ exceeded 25, 50, or $75 \mathrm{kPa}$ during crop growth. Yields and water use were greatest when irrigation was applied at $25 \mathrm{kPa}$. Regression equations are presented to describe the relationships of water use to plant age and to compute the ratios of daily evapotranspiration to pan evaporation (crop factors) for bell pepper grown under the three irrigation regimes.
\end{abstract}

Bell pepper has been classified as susceptible to very susceptible to water stress, with blossom stage being the most sensitive period (Bruce et al., 1980). Sprinkler irrigation to maintain the available soil moisture (ASM) $>50 \%$ increased pepper yields under cool, humid conditions in Canada only during years when rainfall was below normal (O'Sullivan, 1979). Bell pepper yields in India were similar when irrigated at $40 \%$ and $60 \%$ ASM, but yields were reduced when irrigation was applied at either $20 \%$ or $80 \%$ ASM (Hedge, 1987). Marketable yields of 'Bell Boy' pepper grown on a silt loam in Arkansas were increased by trickle irrigation, but yields were similar when irrigation was applied at 30,50 , and $70 \mathrm{kPa}$ soil water tension (Haynes and Herring, 1981). Yields of trickle-irrigated pepper grown under arid conditions in Israel were greater at water applications of 1.33 than $0.83,0.95$, or 1.75 times pan evaporation (Shmueli and Goldberg, 1972). Applying either trickle or sprinkler irrigation when the soil water tension exceeded $75 \mathrm{kPa}$ increased 'Calwonder' pepper yields compared to nonirrigated pepper in New York, but yields of pepper irrigated at 25 and $75 \mathrm{kPa}$ were similar (VanDerwerken and Wilcox-Lee, 1988). When evaporative demand was high, yields of sprinklerirrigated pepper grown on sandy soils in Georgia were greater when irrigated at 25 than at $50 \mathrm{kPa}$ (Batal and Smittle, 1981). Yields of many drought-sensitive vegetable crops have been reduced substantially when the soil water tension was $>25 \mathrm{kPa}$ at irrigation (Bruce et al., 1980; Smittle et al., 1992b; Stansell and Smittle, 1980, 1989). However, pepper yields were less with daily sprinkler irrigation than with irrigation at 5-day intervals (Goldberg and Shmueli, 1971), a result indicating a need to match irrigation to evapotranspiration (ET) to produce maximum pepper yields.

Pan evaporation $\left(\mathrm{E}_{\mathrm{p}}\right)$ incorporates the climatic factors influencing ET into a single measurement (Hansen et al., 1980) and has been used to schedule irrigation for several crops (Jensen and Middleton, 1970). The single crop factor $\left(\mathrm{ET}_{\mathrm{E}} \mathrm{E}_{\mathrm{p}}\right.$ ) value used by Jensen and Middleton (1970) usually resulted in excessive water during some growth periods and water deficits during others. Hansen et al. (1980) present a generalized curve to describe ET/E changes during crop development, but the generalized curve lacks precision. We have developed regression equations to calculate

Received for publication 16 Aug. 1993. Accepted for publication 28 Jan. 1994. Supported by state and Hatch Act funds allocated to the Georgia Agricultural Experiment Stations. The cost of publishing this paper was defrayed in part by the payment of page charges. Under postal regulations, this paper therefore must be hereby marked advertisement solely to indicate this fact.

${ }^{1}$ Dept. of Horticulture.

${ }^{2}$ Dept. of Agricultural Engineering.
ET/E $\mathrm{E}_{\mathrm{p}}$ values used to estimate ET during the growth of several vegetables (Stansell and Smittle, 1980, 1989; Smittle et al., 1990a, 1992b) and have incorporated these equations into irrigation scheduling models (Smittle and Dickens, 1992; Smittle et al., 1990b, 1992a).

In this research, we determined the yield and water use responses of bell pepper to different irrigation regimes. We also developed regression equations to calculate $\mathrm{ET} / \mathrm{E}_{\mathrm{p}}$ during the growth of bell pepper grown under the different irrigation regimes.

\section{Materials and Methods}

During Spring 1982 and 1984 and Fall 1984 and 1985, 'Keystone Resistant Giant' bell pepper was grown in lysimeters containing a Tifton loamy sand soil and a Bonifay sand soil. The Bonifay sand was composed of $92.1 \%$ sand, $2.0 \%$ silt, $4.1 \%$ clay, and $1.8 \%$ organic matter. The Tifton loamy sand was composed of $80.4 \%$ sand, $9.0 \%$ silt, $7.0 \%$ clay, and $3.6 \%$ organic matter. The lysimeter plots were equipped with automatic rainout shelters activated by rainfall (Stansell and Smittle, 1980). Between-plot moisture barriers (1.2 $\mathrm{m}$ deep) and subsurface drains were used to isolate the plots from each other and from groundwater intrusion. Each shelter protected 24 plots of a single soil type that were 1.5 $\times 1.8 \mathrm{~m}$. Each plot contained six resistance block soil moisture sensors placed 10, 23, 38, 53, 81, and $107 \mathrm{~cm}$ deep. The sensors were read daily beginning at $0800 \mathrm{HR}$ by a data collection system controlled by an on-site computer. The data were processed by the computer and a daily report was printed that included the soil water content at each sensor depth and the irrigation requirements for the day. Soil water data were stored for future analyses. A shelter contained 12 plots of bell pepper. Irrigation treatments within the eight year-season-soil type combinations were arranged in a randomized complete-block design with four replications.

For 10 days after transplanting, water was applied at 2- to 3-day intervals with a hand-held sprinkler nozzle. After this time, irrigations were scheduled by measured soil water deficits. Treatments consisted of irrigating at soil water tensions of 25,50 , or $75 \mathrm{kPa}$. When sensors $10 \mathrm{~cm}$ deep showed soil water deficits corresponding to the treatment requirements, water was applied to refill the surface $30 \mathrm{~cm}$ of the soil profile to field capacity $(8 \mathrm{kPa})$. The amount of water applied represented the average of the four replications and was determined from water retention curves for the soil (Stansell and Smittle, 1980).

Climatological data, including rainfall, open pan evaporation, wind movement, relative humidity, and maximum and minimum 
air temperatures were collected daily at the research site.

Plots were hand-tilled to incorporate fertilizers applied at $40 \mathrm{~N}-$ $35 \mathrm{P}-100 \mathrm{~K}\left(\mathrm{~kg} \cdot \mathrm{ha}^{-1}\right)$. Transplants were planted by hand on $15 \mathrm{Mar}$. 1982, 16 Mar. 1984, 8 Sept. 1984, and 29 Mar. 1985. Plants were spaced $30 \mathrm{~cm}$ apart in 91-cm rows. Nitrogen was broadcastapplied at $34 \mathrm{~kg} \mathrm{~N} / \mathrm{ha}$ as $\mathrm{Ca}\left(\mathrm{NO}_{3}\right)_{2} 3,5$, and 7 weeks after transplanting.

Plots were harvested at weekly intervals for 4 weeks beginning on 17 May 1982, 28 May 1984, 17 Oct. 1984, and 7 June 1985. The fruit were graded and the number and weight of total, marketable, US fancy, US no. 1, US no. 2, and culls were determined. Yield data for the irrigation regimes were subjected to regression analyses, wherein the eight year-season-soil type combinations were considered as separate experiments.

Water applied should be a valid estimate of ET since the plots were protected from rainfall and groundwater intrusion and water was added based on water content at various depths in the soil profile. Sufficient water ( 55 to $75 \mathrm{~mm}$ ) was applied during the first 10 days after transplanting to ensure recharge of the soil profile. Data for water applications and $\mathrm{E}_{\mathrm{p}}$ during these periods were not included in the calculation of ET and $\mathrm{E}_{\mathrm{p}}$ rates since the amount of water applied at the last irrigation would also recharge the soil profile. Daily ET rates were determined by dividing the depth of water applied to each plot at each irrigation by the number of days since the last irrigation. Daily $\mathrm{E}_{\mathrm{p}}$ rates were measured from a U.S. Weather Bureau class A pan. Data for ET and $\mathrm{E}_{\mathrm{p}}$ rates on the date of irrigation were used to calculate ET/E $\mathrm{E}_{\mathrm{p}}$ values. Regression equations were developed to describe changes in ET, E, and ET/ $\mathrm{E}_{\mathrm{p}}$ with age using SAS's general linear models procedure (SAS Institute, 1982).

\section{Results and Discussion}

$\mathrm{E}_{\mathrm{p}}$ was $39 \%$ greater when bell pepper was grown during the spring than the fall (Table 1). Also, more water was applied when bell pepper was grown during the spring than the fall. During the period when irrigations were determined by soil water tension 10 $\mathrm{cm}$ deep, 11 to 29 irrigations were required to maintain the maximum soil water tensions below the desired level. Although the amount of water applied at each irrigation decreased as the soil water tensions at the time of irrigation decreased from 75 to $25 \mathrm{kPa}$, less total water was usually applied to bell pepper that was subjected to water stress levels of 50 and 75 than to $25 \mathrm{kPa}$. These results follow the general trend that crops receiving more frequent irrigations have had greater water use than crops receiving less frequent irrigations under similar climatic conditions (Bruce et al., 1980; Stansell and Smittle, 1980, 1989).

All of the crops showed significant marketable fruit yield responses to the irrigation regimes (Table 2). Average marketable fruit yields were $30.5,26.5$, and $21.8 \mathrm{t} \cdot \mathrm{ha}^{-1}$ when bell pepper was irrigated at 25,50 , and $75 \mathrm{kPa}$, respectively. The yield increase with irrigation at $25 \mathrm{kPa}$ compared to $50 \mathrm{kPa}$ was greater for this

Table 1. Effect of production seasons and soil types on pan evaporation and water use by 'Keystone Resistant Giant' bell peppers grown under three irrigation regimes. ${ }^{\mathrm{z}}$

\begin{tabular}{|c|c|c|c|c|}
\hline \multirow[b]{3}{*}{ Year-season-soil } & \multirow{3}{*}{$\begin{array}{c}\text { Pan } \\
\text { evaporation } \\
(\mathrm{mm})\end{array}$} & \multicolumn{3}{|c|}{$\begin{array}{l}\text { Irrigation regime } \\
(\mathrm{kPa})\end{array}$} \\
\hline & & 25 & 50 & 75 \\
\hline & & \multicolumn{3}{|c|}{ Water applied $(\mathrm{mm})^{\mathrm{y}}$} \\
\hline 1982-Spring-Tifton & 463 & $311(27)$ & $255(16)$ & $207(11)$ \\
\hline 1984-Spring-Tifton & 587 & $269(19)$ & $264(15)$ & $258(13)$ \\
\hline 1984-Spring-Bonifay & 587 & $280(17)$ & $275(14)$ & $225(11)$ \\
\hline 1984-Fall-Tifton & 425 & $221(22)$ & $213(17)$ & $200(12)$ \\
\hline 1984-Fall-Bonifay & 425 & $251(16)$ & 237 (14) & $245(12)$ \\
\hline 1984-Fall-Bonifay & 425 & $242(17)$ & $228(13)$ & $218(12)$ \\
\hline 1985-Spring-Tifton & 656 & $396(25)$ & 387 (18) & $380(17)$ \\
\hline 1985-Spring-Tifton & 656 & $380(29)$ & $349(21)$ & $295(18)$ \\
\hline
\end{tabular}

${ }^{\mathrm{Z} P l o t s}$ were irrigated when soil water tension at $10 \mathrm{~cm}$ was 25,50 , or $75 \mathrm{kPa}$.

${ }^{y}$ Numbers in parentheses are the number of irrigations applied to each irrigation regime.

Table 2. Effect of irrigation regime ${ }^{\mathrm{z}}$ on marketable yield of 'Keystone Resistant Giant' bell peppers.

\begin{tabular}{|c|c|c|c|c|}
\hline \multirow[b]{3}{*}{ Crop } & \multicolumn{3}{|c|}{$\begin{array}{l}\text { Irrigation regime } \\
\qquad(\mathrm{kPa})\end{array}$} & \multirow[b]{3}{*}{ Significance } \\
\hline & 25 & 50 & 75 & \\
\hline & \multicolumn{3}{|c|}{ Fruit yield $\left(\mathrm{t} \cdot \mathrm{ha}^{-1}\right)$} & \\
\hline 1982-Spring-Tifton & 33.2 & 31.0 & 23.4 & $\mathrm{~L}^{* *}, \mathrm{Q}^{*}$ \\
\hline 1984-Spring-Tifton & 25.8 & 21.9 & 16.3 & $\mathrm{~L}^{*}$ \\
\hline 1984-Spring-Bonifay & 18.4 & 17.2 & 11.8 & $\mathrm{~L}^{*}, \mathrm{Q}^{* * *}$ \\
\hline 1984-Fall-Tifton & 26.9 & 23.7 & 19.5 & $\mathrm{~L}^{* * *}$ \\
\hline 1984-Fall-Bonifay & 24.2 & 26.2 & 20.0 & $\mathrm{Q}^{* *}$ \\
\hline 1984-Fall-Bonifay & 26.3 & 25.0 & 19.0 & $\mathrm{~L}^{* *}, \mathrm{Q}^{*}$ \\
\hline 1985-Spring-Tifton & 43.3 & 32.9 & 34.8 & $\mathrm{Q}^{*}$ \\
\hline 1985-Spring-Tifton & 46.1 & 34.0 & 29.9 & $\mathrm{~L}^{* *}, \mathrm{Q}^{*}$ \\
\hline
\end{tabular}

${ }^{\mathrm{z} P l o t s}$ were irrigated when soil water tension at $10 \mathrm{~cm}$ was 25,50 , or $75 \mathrm{kPa}$.

**** Significant at $P=0.05$ or $0.01 ; \mathrm{L}=$ linear, $\mathrm{Q}=$ quadratic effects of irrigation regimes. 
experiment than reported earlier for the same soil type (Batal and Smittle, 1981). Bell pepper in this experiment received only the water applied by irrigation; whereas, bell pepper of the earlier field test received $122 \mathrm{~mm}$ of water as rainfall during the period from week 4 through 12 after transplanting.

Yields of fancy peppers showed significant linear responses to irrigation regimes for seven of the eight crops (Table 3). Fancy fruit yields were greater with irrigation at 25 than at 50 or $75 \mathrm{kPa}$ for all crops. Average fancy fruit yields were 10.3, 6.7, and 4.1 th ha ${ }^{-1}$ when irrigated at 25,50 , and $75 \mathrm{kPa}$, respectively. Fancy fruit yields represent $34 \%, 25 \%$, and $19 \%$ of the marketable yield of pepper irrigated at 25,50 , and $75 \mathrm{kPa}$, respectively.

The large, well-shaped fruit of the US fancy grade generally command a price of about $\$ 675 / \mathrm{t}$ (Mizelle, 1991). Using this price, returns from US fancy grade bell pepper would be $\$ 6950, \$ 4220$, and $\$ 2770 /$ ha when irrigated at 25,50 , and $75 \mathrm{kPa}$, respectively. Average water application rates of 294, 276, and $253 \mathrm{~mm}$, for the 25,50 , and $75 \mathrm{kPa}$ irrigation treatments reflect irrigation cost reductions of about $\$ 10 /$ ha for the $50 \mathrm{kPa}$ and $\$ 20 /$ ha for the $75 \mathrm{kPa}$ irrigation treatments. These results show that more frequent irrigations with less water per irrigation increased marketable yield, grade, and returns of 'Keystone Resistant Giant' bell pepper.

ET and $\mathrm{E}_{\mathrm{p}}$ data for the growth period from 10 to 14 days after transplanting until the last irrigation were used to develop regres- sion equations to describe ET and ET/E values. Daily $\mathrm{E}_{\mathrm{p}}$ rates varied from $0 \mathrm{~mm}$ to $8 \mathrm{~mm}$ during the 2 - to 9 -day periods of water use between irrigations; however, the $\mathrm{E}_{\mathrm{p}}$ rates generally increased during the spring and decreased during the fall.

The regression equations for ET accurately estimate the amount of water used by bell pepper only if the evaporative demand conditions were similar to those of these tests and are not presented. However, the ET/E values provide a method of adjusting the water-use rates to compensate for variations in climatic conditions that influence evaporative demand.

The regression equations to describe ET/E values accounted for $96 \%$ to $99 \%$ of the variations of $\mathrm{ET} / \mathrm{E}$ for the three irrigation regimes of the eight bell pepper crops (Table 4). The similarity of regression equations for the crop-irrigation regime combinations indicate that much of the variation in water-use estimation due to climatic differences could be eliminated by calculating ET/E values. $\mathrm{ET} / \mathrm{E}_{\mathrm{p}}$ values produced by these regression equations were slightly lower when bell pepper plants were irrigated at soil water tensions of 50 and 75 rather than $25 \mathrm{kPa}$. For example, ET/E values with all crops combined were $0.80,0.77$, and 0.73 when 75 day old bell pepper was irrigated at 25,50 , and $75 \mathrm{kPa}$, respectively. These results agree with our earlier research (Bruce et al., 1980; Stansell and Smittle, 1980, 1989) that more water is required when crops are irrigated more frequently. Stegman et al. (1980)

Table 3. Effect of irrigation regime ${ }^{\mathrm{z}}$ on yield of fancy 'Keystone Resistant Giant' bell peppers.

\begin{tabular}{|c|c|c|c|c|}
\hline \multirow[b]{3}{*}{ Crop } & \multicolumn{3}{|c|}{$\begin{array}{l}\text { Irrigation regime } \\
(\mathrm{kPa})\end{array}$} & \multirow[b]{3}{*}{ Significance } \\
\hline & 25 & 50 & 75 & \\
\hline & \multicolumn{3}{|c|}{ Fruit yield $\left(\mathrm{t} \cdot \mathrm{ha}^{-1}\right)$} & \\
\hline 1982-Spring-Tifton & 7.5 & 4.9 & 2.5 & $\mathrm{~L}^{* *}$ \\
\hline 1984-Spring-Tifton & 8.8 & 4.0 & 3.0 & $\mathrm{Q}^{* *}$ \\
\hline 1984-Spring-Bonifay & 7.4 & 4.7 & 2.4 & $\mathrm{~L}^{* * *}, \mathrm{Q}^{*}$ \\
\hline 1984-Fall-Tifton & 11.2 & 6.8 & 2.4 & $\mathrm{~L}^{* *}$ \\
\hline 1984-Fall-Bonifay & 10.4 & 6.9 & 4.2 & $\mathrm{~L}^{* *}$ \\
\hline 1984-Fall-Bonifay & 11.7 & 8.2 & 4.2 & $\mathrm{~L}^{* *}$ \\
\hline 1985-Spring-Tifton & 13.0 & 8.9 & 7.7 & $\mathrm{~L}^{* *}, \mathrm{Q}^{* *}$ \\
\hline 1985-Spring-Tifton & 12.2 & 9.0 & 6.3 & $\mathrm{~L}^{* * *}$ \\
\hline
\end{tabular}

${ }^{\mathrm{z} P l o t s}$ were irrigated when soil water tension at $10 \mathrm{~cm}$ was 25,50 , or $75 \mathrm{kPa}$.

${ }^{*},{ }^{* *}$ Significant at $P=0.05$ or $0.01 ; \mathrm{L}=$ linear, $\mathrm{Q}=$ quadratic effects of irrigation regimes.

Table 4. Effect of production seasons and soil types on regression equations to describe crop factors (ET/E p $_{\mathrm{p}}$ change with age $\mathrm{e}^{\mathrm{z}}(\mathrm{A})$ of 'Keystone Resistant Giant' bell peppers grown under three irrigation regimes. ${ }^{y}$

\begin{tabular}{|c|c|c|c|}
\hline \multirow[b]{3}{*}{ Year-season-soil } & \multicolumn{3}{|c|}{ Irrigation regime $(\mathrm{kPa})$} \\
\hline & 25 & 50 & 75 \\
\hline & \multicolumn{3}{|c|}{ Regression } \\
\hline 1982-Spring-Tifton & $0.0178 \mathrm{~A}-0.00009 \mathrm{~A}^{2}$ & $0.0171 \mathrm{~A}-0.00008 \mathrm{~A}^{2}$ & $0.0169 \mathrm{~A}-0.00010 \mathrm{~A}^{2}$ \\
\hline 1984-Spring-Tifton & $0.0138 \mathrm{~A}-0.00006 \mathrm{~A}^{2}$ & $0.0137 \mathrm{~A}-0.00006 \mathrm{~A}^{2}$ & $0.0164 \mathrm{~A}-0.00010 \mathrm{~A}^{2}$ \\
\hline 1984-Spring-Bonifay & $0.0131 \mathrm{~A}-0.00005 \mathrm{~A}^{2}$ & $0.0150 \mathrm{~A}-0.00007 \mathrm{~A}^{2}$ & $0.0138 \mathrm{~A}-0.00007 \mathrm{~A}^{2}$ \\
\hline 1984-Fall-Tifton & $0.0254 \mathrm{~A}-0.00021 \mathrm{~A}^{2}$ & $0.0228 \mathrm{~A}-0.00016 \mathrm{~A}^{2}$ & $0.0226 \mathrm{~A}-0.00017 \mathrm{~A}^{2}$ \\
\hline 1984-Fall-Bonifay & $0.0207 \mathrm{~A}-0.00012 \mathrm{~A}^{2}$ & $0.0235 \mathrm{~A}-0.00017 \mathrm{~A}^{2}$ & $0.0220 \mathrm{~A}-0.00015 \mathrm{~A}^{2}$ \\
\hline 1984-Fall-Bonifay & $0.0236 \mathrm{~A}-0.00017 \mathrm{~A}^{2}$ & $0.0194 \mathrm{~A}-0.00012 \mathrm{~A}^{2}$ & $0.0202 \mathrm{~A}-0.00014 \mathrm{~A}^{2}$ \\
\hline 1985-Spring-Tifton & $0.0201 \mathrm{~A}-0.00012 \mathrm{~A}^{2}$ & $0.0186 \mathrm{~A}-0.00011 \mathrm{~A}^{2}$ & $0.0185 \mathrm{~A}-0.00011 \mathrm{~A}^{2}$ \\
\hline 1985-Spring-Tifton & $0.0204 \mathrm{~A}-0.00012 \mathrm{~A}^{2}$ & $0.0160 \mathrm{~A}-0.00008 \mathrm{~A}^{2}$ & $0.0177 \mathrm{~A}-0.00010 \mathrm{~A}^{2}$ \\
\hline Spring crops & $0.0180 \mathrm{~A}-0.00010 \mathrm{~A}^{2}$ & $0.0167 \mathrm{~A}-0.00009 \mathrm{~A}^{2}$ & $0.0161 \mathrm{~A}-0.00009 \mathrm{~A}^{2}$ \\
\hline Fall crops & $0.0252 \mathrm{~A}-0.00020 \mathrm{~A}^{2}$ & $0.0222 \mathrm{~A}-0.00016 \mathrm{~A}^{2}$ & $0.0220 \mathrm{~A}-0.00016 \mathrm{~A}^{2}$ \\
\hline All crops & $0.0196 \mathrm{~A}-0.00012 \mathrm{~A}^{2}$ & $0.0186 \mathrm{~A}-0.00011 \mathrm{~A}^{2}$ & $0.0184 \mathrm{~A}-0.00012 \mathrm{~A}^{2}$ \\
\hline
\end{tabular}

${ }^{\mathrm{z} A g e}$ expressed as days after transplanting.

yPlots were irrigated when soil water tension at $10 \mathrm{~cm}$ was 25,50 , or $75 \mathrm{kPa}$. 
showed that the ET rate was elevated for a short period after irrigation due to evaporation of water from soil and plant surfaces.

The ET for a specific age of bell pepper can be estimated by multiplying the $\mathrm{E}_{\mathrm{p}}$ value, measured from an evaporation pan, by the ET/E $/ \mathrm{E}_{\mathrm{p}}$ value calculated from the regression equations of Table 4. For example, 50 days after transplanting, the $\mathrm{ET} / \mathrm{E}_{\mathrm{p}}$ value for a spring crop of bell peppers would be $0.65\left(0.018 \mathrm{~A}-0.0001 \mathrm{~A}^{2}\right)$ if irrigation were applied at $25 \mathrm{kPa}$. The ET of these bell peppers on this date would be $2.6 \mathrm{~mm}(4 \times 0.65)$ if $\mathrm{E}_{\mathrm{p}}$ were $4 \mathrm{~mm}$ and $5.2 \mathrm{~mm}$ $(8 \times 0.65)$ if $\mathrm{E}_{\mathrm{p}}$ were $8 \mathrm{~mm}$.

The maximum ET/E values calculated from these regression equations were similar for all crops. At 75 days after transplanting, $\mathrm{ET} / \mathrm{E}_{\mathrm{p}}$ values were $0.79,0.77$, and 0.80 , respectively, for spring crops, fall crops, and all crops irrigated at $25 \mathrm{kPa}$. The pattern of $\mathrm{ET} / \mathrm{E}_{\mathrm{p}}$ change with age varied slightly for bell pepper grown during the spring and fall (Fig. 1). Using ET/E values where all data were combined would not greatly affect the accuracy of estimating daily ET for bell pepper grown during the spring, but using the equation having all data combined for fall-grown bell pepper would underestimate ET during early growth and overestimate ET during late growth. For example, when data for all crops were combined, the $\mathrm{ET} / \mathrm{E}_{\mathrm{p}}$ values for 45 - and 90-day old bell pepper irrigated at $25 \mathrm{kPa}$ were 0.64 and 0.79 , respectively. On the other hand, when data for only the fall crops were used, ET/E values for 45- and 90-day old bell pepper irrigated at $25 \mathrm{kPa}$ crops were 0.73 and 0.65 , respectively.

If $\mathrm{E}_{\mathrm{p}}$ were $5 \mathrm{~mm} / \mathrm{day}$, using the regressions for all crops to calculate the ET/E for 45 -day old bell pepper grown during the fall would introduce an error in estimating an ET of $\approx 0.45 \mathrm{~mm} /$ day. This magnitude of error in estimating ET may not greatly affect an irrigation scheduling model (Smittle et al., 1990b, 1992b) in the humid southeastern United States because the soil water reservoir within the root system is small and rainfall in excess of accumulated ET is relatively common. However, an accumulation of this magnitude of ET estimation error in arid areas could introduce a serious water stress near blossom stage if the regression equation for all crops was used to schedule irrigations for a fall crop.

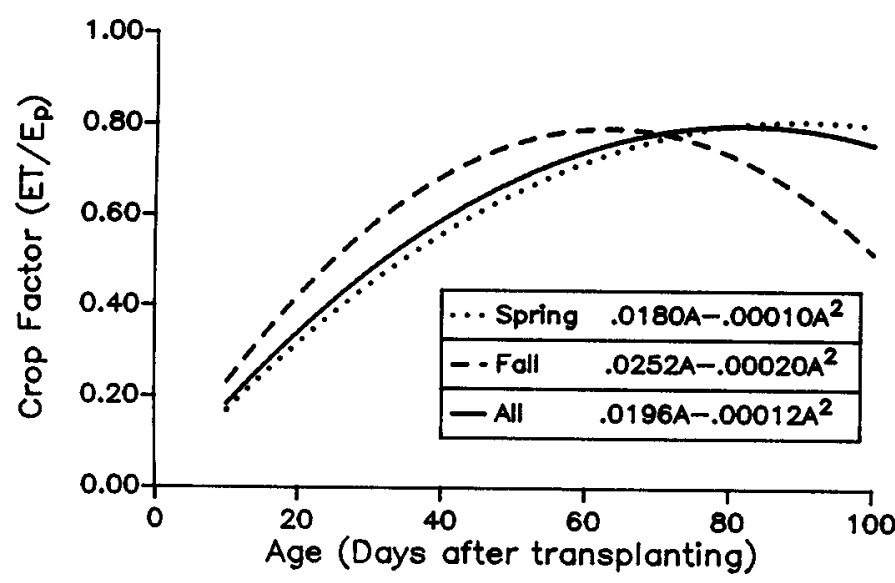

Fig. 1. Daily crop factor values for 'Keystone Resistant Giant' bell peppers grown as a spring or fall crop or when all crops were included in the regression.
We have shown that marketable and fancy yield of bell pepper was greatest with irrigation applications when the soil water tension at $10 \mathrm{~cm}$ was $<25 \mathrm{kPa}$. This irrigation regime also resulted in more frequent applications and required more water than irrigation applications at soil water tensions of 50 and $75 \mathrm{kPa}$. Regression equations were developed to compute $\mathrm{ET} / \mathrm{E}_{\mathrm{p}}$ values during bell pepper growth. These equations provide a daily adjustment for $\mathrm{E}_{\mathrm{p}}$ that allows $\mathrm{E}$ to be used to develop irrigation scheduling models (Smittle and Dickens, 1992; Smittle et al., 1990b, 1992b).

\section{Literature Cited}

Batal, K.M. and D.A. Smittle. 1981. Response of bell pepper to irrigation, nitrogen and plant population. J. Amer. Soc. Hort. Sci. 106:259-262.

Bruce, R.R., J.L. Chesness, T.C. Keisling, J.E. Pallas, Jr., D.A. Smittle, J.R. Stansell, and A.W. Thomas. 1980. Irrigation of crops in the southeastern United States: Principles and practices. U.S. Dept. Agr., Sci. Ed. Admin. Agr. Rev. Man. ARM-S-9.

Goldberg, D. and M. Shmueli. 1971. Sprinkle and trickle irrigation of green peppers in an arid zone. HortScience 6:559-562.

Hansen, V.E., O.W. Israelsen, and G.E. Stringham. 1980. Irrigation principles and practices. 4th ed. Wiley, New York.

Haynes, R. and S. Herring. 1981. Performance of drip-irrigated bell peppers. Arkansas Farm Res. 30(3):12.

Hedge, D. M. 1987. Growth analysis of bell pepper (Capsicum annuum L.) in relation to soil moisture and nitrogen fertilization. Scientia Hort. 33:179-187.

Jensen, M.E. and J.E. Middleton. 1970. Scheduling irrigation from pan evaporation. Wash. Agr. Expt. Sta. Circ. 527.

Mizelle, W.O. 1991. Vegetable economics: 1987-1991 prices. Univ. of Georgia Ext. Agr. Econ. Misc. Publ. 91-013.

O'Sullivan, J. 1979. Response of bell pepper to irrigation and nitrogen. Can. J. Plant Sci. 59:1085-1091.

SAS Institute. 1982. SAS user's guide: Statistics. SAS Inst., Cary, N.C. Shmueli, M. and D. Goldberg. 1972. Response of trickle-irrigated pepper in an arid zone to various water regimes. HortScience 7:241-243.

Smittle, D.A. and W.L. Dickens. 1992. Water budgets to schedule irrigation for vegetables. HortTechnology 2:54-59.

Smittle, D.A., W.L. Dickens, and M.J. Hayes. 1992a. An irrigation scheduling model for summer squash. J. Amer. Soc. Hort. Sci. 117:717720.

Smittle, D.A., W.L. Dickens, and J.R. Stansell. 1990b. An irrigation scheduling model for snap beans. J. Amer. Soc. Hort. Sci. 115:226-230.

Smittle, D.A., W.L. Dickens, J.R. Stansell, and E. Simonne. 1992b. Irrigation regimes affect leaf yield and water use by turnip and mustard. HortScience 27:308-310.

Smittle, D.A., M.R. Hall, and J.R. Stansell. 1990a. Effects of irrigation regimes on yield and water use by sweet potato. J. Amer. Soc. Hort. Sci. 115:712-714.

Stansell, J.R. and D.A. Smittle. 1980. Effects of irrigation regimes on yield and water use of snap beans (Phaseolus vulgaris L.). J. Amer. Soc. Hort Sci. 105:869-873.

Stansell, J.R. and D.A. Smittle. 1989. Effects of irrigation regimes on yield and water use of summer squash. J. Amer. Soc. Hort. Sci. 114:196199.

Stegman, E.C., J.R. Musick, and J.L. Stewart. 1980. Irrigation water management, p. 763-816. In: M.E. Jensen (ed.). Design and operation of farm irrigation systems. Amer. Soc. Agr. Eng., St. Joseph, Mich.

VanDerwerken, J.E. and D. Wilcox-Lee. 1988. Influence of plastic mulch and type and frequency of irrigation on growth and yield of bell pepper. HortScience 23:985-988. 